Т.С. Головко, В.С. Іванкова, О.О. Бакай, Л.А. Шевчук, Л.М. Барановська

\title{
Променеві методи дослідження у моніторингу лікування хворих на метастатичний рак піхви
}

\author{
Національний інститут раку, Київ \\ Одержано 01.04.2019 \\ Прийнято до друку 15.04.2019 \\ DOI: 10.32471/clinicaloncology.2663-466X.38.22322
}

\begin{abstract}
Головне завдання динамічного спостереження пацієнток у віддалені строки після проведення консервативного лікування - своєчасне виявлення рецидиву захворювання. Для цього застосовують променеві методи, насамперед ультразвукове дослідження (УЗД) та магнітно-резонансну томографію (МРТ). Мета роботи - визначити інформативність променевих методів дослідження у моніторингу лікування хворих з метастатичним раком піхви. Об'єкт і методи дослідження. Проведено комплексне променеве обстеження із застосуванням УзД та МРТ у 20 хворих на метастатичний рак піхви до, під час та після поєднаного променевого лікування на тлі використання хіміорадіомодифікаторів для оцінки його ефективності. Контрольна група - 10 пацієнток без ознак продовження хвороби. УЗ- та МР-семіотику зіставлено з клінічним перебігом хвороби та даними морфологічного дослідження. Результати. Визначено УЗ- та МР-ознаки метастатичного раку піхви та його регресу при консервативному лікуванні. Чутливість, специфічність і точність для виявлення метастатичного раку піхви при УзД становили 75,0; 80,0 та 76,7\% відповідно, а при МРТ - 85,0; 90,0 та 86,6\% відповідно. Чутливість, специфічність і точність оцінки ефективності консервативної терапії метастатичного раку піхви при УзД становили 62,5; 75,0 та 65,0\%, при МРТ 75,0; 87,0 та 77,5\% відповідно. Висновки. УзД та МРТ є інформативними методами для виявлення та оцінки ефективності консервативної терапії метастатичного раку піхви.
\end{abstract}

Ключові слова: ультразвукова діагностика; магнітно-резонансна томографія; метастатичний рак піхви; хіміопроменева терапія.

Головне завдання динамічного спостереження пацієнток у віддалені строки після проведення консервативного лікування - своєчасне виявлення рецидиву захворювання.

Окрім клінічного, гінекологічного та цитологічного обстеження, кольпоскопії, обов'язкового гістологічного дослідження, для виявлення продовження хвороби, оцінки розповсюдження процесу і точного визначення розмірів метастатичних пухлин використовують променеві методи діагностики.

Найбільш поширеним та інформативним методом діагностики при захворюваннях органів малого таза у жінок $є$ ультразвукове дослідження (УЗД). Висока інформативність, простота проведення, можливість багаторазового повторення роблять УЗД пріоритетним серед інших методів візуалізаціі у виявленні продовження захворювання та для моніторингу в процесі лікування.

За сучасними даними, завдяки впровадженню в практику трансвагінального УЗД з високою частотою сканування (9-12 Мц) можливо якісно візуалізувати не тільки шийку та тіло матки з придатками, а й піхву, виявляти новоутворення в ній, визначати ступінь поширення пухлинного процесу. Інформативним є вивчення васкуляризації в піхві та пухлинах за допомогою візуалізації внутрішньопухлинного кровотоку та особливостей кровопостачання прилеглих до осередку анатомічних структур. У нормі в піхві, як і в стромі шийки матки, при кольоровому (КДК) та енергетичному допплерівському картуванні (ЕДК) реєструють лише поодинокі кольорові локуси. При спектрографії в судинах піхви максимальна систолічна швидкість кровотоку $\left(\mathrm{V}_{\max }\right)$ становить $5-10 \mathrm{~cm} / \mathrm{c}$, індекс резистентності (RI) 0,5-0,7.

Проте існує низка серйозних застережень, які часто ускладнюють повноцінне обстеження пацієнток за допомогою УЗД: обмеження поля зору, залежність можливостей обстеження від стану кишечнику, надлишкова маса тіла хворої. УЗД не завжди може виявити новоутворення в піхві, забезпечити точну оцінку ступеня поширення пухлинного процесу. Означені недоліки методу не дозволяють обмежитися при новоутвореннях малого таза застосуванням лише УЗД, а потребують залучення додаткових методів.

На етапі уточнювальної діагностики найчастіше використовують магнітно-резонансну томографію (МРТ), яка має вищу чутливість для оцінки м'якотканинних утворень і на сьогодні вважається найбільш інформативним методом для виявлення патології піхви, $є$ основою для планування лікування та оцінки регресії пухлини при консервативній терапії. Безсумнівною перевагою МРТ є висока диференціація м'яких тканин, яка необхідна при обстеженні внутрішніх геніталій, можливість отримання багатоплощинних проекцій i, звичайно, безпека за рахунок відсутності іонізуючого випромінювання. Високе контрастування м'яких тканин дає можливість при МРТ детально вивчити піхву та ступінь їі залучення в пухлинний процес. Для цього найбільш інформативні послідовності Т2-зважених зображень (T2-33) у сагітальній площині; поширення пухлинного процесу в піхву реєструють при наявності посилення сигналу від ії стінок та їх потовщення. На Т2-33 в сагітальній та аксіальній площинах визначають локалізацію пухлини, iіi розміри і глибину інвазії. Під час інтерпретації магнітно-резонансних (МР)-зображень враховують наступне: на Т2-33 пухлина характеризується гіперінтенсивним сигналом стосовно гіпоінтенсивної строми; на Т1-33 гіпо- або ізоінтенсивними стосовно міометрію можуть виявлятися підвищені сигнали при крововиливах усередині ушкодження. МРТ з контрастним підсиленням дозволяє уточнити розміри і глибину інвазії пухлини, у тому числі виявляти пухлини невеликих розмірів з глибиною інвазії 5,0 мм. Також це оптимізує диференціювання рецидивної пухлини і постпроменевого фіброзу. МРТ служить основою для планування хіміопроменевої терапії (ХПТ) та є одним із провідних методів об'єктивної оцінки регресії пухлини внаслідок лікування.

Мета роботи - визначити інформативність променевих методів дослідження у моніторингу лікування хворих на метастатичний рак піхви.

\section{ОБ'ЄКТ I МЕТОДИ ДОСЛІДЖЕННЯ}

Проведено променеве дослідження у 20 хворих на метастатичний рак піхви, які проходили лікування у Національному інституті раку. Вік жінок становив від 32 до 61 року. Контрольна група сформована 310 пацієнток без ознак продовження хвороби. Усім пацієнткам проводили комплексне променеве обстеження із застосуванням УЗД та МРТ. Ультразвукову (УЗ)- та МРсеміотику зіставлено $з$ клінічним перебігом хвороби та даними морфологічного дослідження. 
Променеве дослідження малого таза проводили до, під час та після поєднаного променевого лікування на тлі використання хіміорадіомодифікаторів для оцінки його ефективності за стандартною методикою на діагностичному УЗ-апараті Philips із застосуванням різних методик картування, включаючи ЕДК, КДК та спектральну допплерометрію, МРТ проводили на томографах Philips (Intera) з напруженістю магнітного поля 1,5 Т, з контрастним підсиленням гадолінієвими препаратами в стандартному дозуванні (0,2 мл/кг маси тіла хворого).

\section{РЕЗУЛЬТАТИ}

Після консервативної терапії хворих на рак шийки матки (РШМ) з досягненням клінічного ефекту шийка матки була невеликих розмірів $\left(12,0 \pm 5,6 \mathrm{~cm}^{3}\right)$, з чіткими та рівними контурами, відмічали дещо збільшену кількість гіперехогенних включень фіброзу, за рахунок чого структура була неоднорідною в 44,7\% випадків. Через 3 та 6 міс внаслідок розвитку фіброзних змін при допплерографії у судинах реєстрували лише поодинокі локуси, переважно по периферії шийки матки, з низькою систолічною $\mathrm{V}_{\max } 7,2 \pm 3,1 \mathrm{~cm} / \mathrm{c}$, високою резистентністю кровотоку $\mathrm{RI}=0,79 \pm 0,2$. За відсутності рецидиву піхва була однорідної структури, з чіткими та рівними контурами. Стінки піхви були рівномірної товщини до 8-10 мм (рис. 1).

На МРТ під час контрольних обстежень після лікування шийка матки та піхва, за відсутності рецидиву, мають середню інтенсивність МР-сигналу на Т2-33, у структурі шийки матки та в навколишніх тканинах часто виявляють фіброз у вигляді тяжистих включень зниженої інтенсивності на Т233. На постконтрастних Т1-33 шийка матки та піхва помірно накопичують контрастну речовину (рис. 2).

У разі продовження хвороби метастатичні пухлини візуалізували у вигляді утворень на піхві неправильної форми, неоднорідної структури, з горбистими контурами. При будьякому пухлинному ураженні відбувається утворення патологічних судин зі зміненою стінкою. Останні не можуть бути визнані повноцінними унаслідок незакінченої диференціації, проте забезпечують достатнє для подальшого розвитку пухлини кровопостачання. Через продукцію факторів ангіогенезу злоякісні новоутворення в процесі свого росту стимулюють розвиток власної судинної мережі. Активне кровопостачання забезпечує умови для прогресування захворювання, а характерною ознакою найбільш агресивних новоутворень $\epsilon$ наявність множинних атипових, хаотично розташованих мікросудин та артеріовенозних шунтів. Такі судини мають дуже низький периферичний опір, при спектрографії реєструють низькорезистентний кровотік та високу систолічну швидкість (рис. 3). Таким чином, УЗ-ознаками продовження хвороби було: наявність новоутворення в піхві $(86,7 \%)$, з нерівними та нечіткими контурами, неоднорідною структурою $(92,0 \%)$,

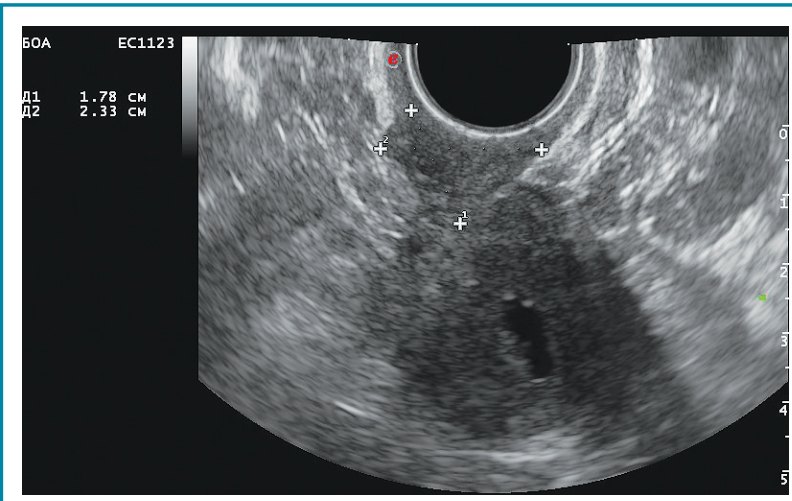

Рис. 1. Ехограма матки та піхви після ХПТ за відсутності продовження хвороби. РШМ стадії ТЗа, стан після ХПТ, даних про продовження хвороби немає, післяпроменеві фіброзні зміни. Стінки піхви не потовщені, з чіткими рівними контурами, однорідною структурою

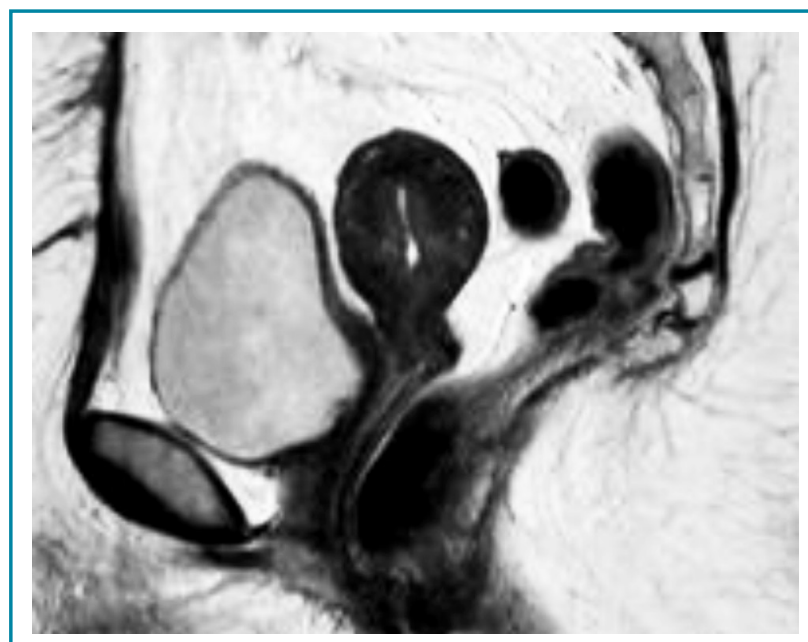

Рис. 2. МРТ матки та піхви після ХПТ за відсутності продовження хвороби. РШМ ТЗа стадії, стан після ХПТ, даних про продовження хвороби немає, післяпроменеві фіброзні зміни. Стінки піхви не потовщені, з чіткими рівними контурами, МР-сигнал не змінений

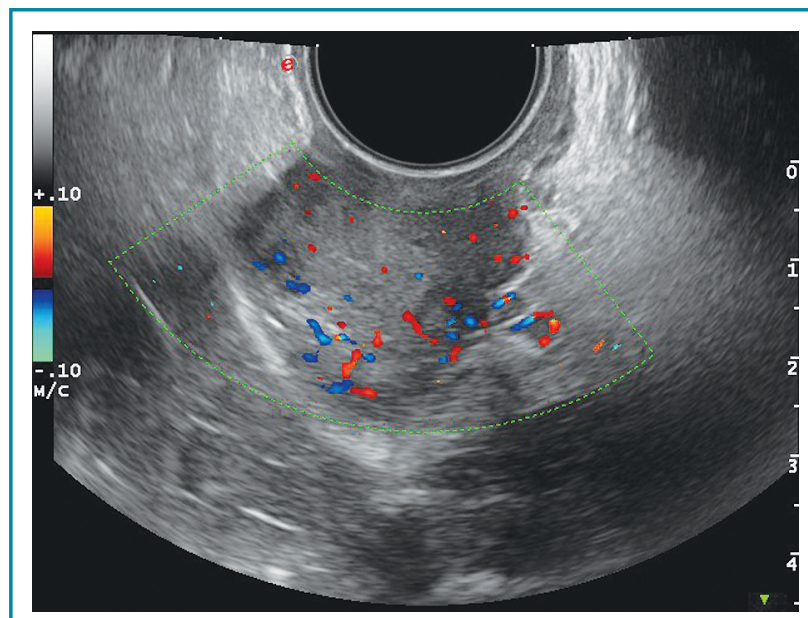

Рис. 3. Ехограма метастатичної пухлини РШМ на культі піхви. РШМ ТЗа, стан після ХПТ, метастатична пухлина на культі піхви. Утворення з горбистими контурами та атиповим кровотоком

наявністю атипового кровотоку $(91,6 \%), \mathrm{V}_{\max } 30,0 \pm 9,1 \mathrm{~cm} / \mathrm{c}$, RI $0,5 \pm 0,1$.

Якщо метастатична пухлина локалізувалася в склепіннях піхви, пухлинний процес поширювався на нижні відділи шийки матки (рис. 4). В однієї пацієнтки спостерігали тотальне метастатичне ураження піхви (рис. 5).

Високе контрастування м'яких тканин дає можливість при МРТ детально вивчити піхву та ступінь іï залучення у пухлинний процес. Для цього найбільш інформативними $€$ послідовності Т2-33; поширення пухлинного процесу на піхву реєструють за наявності підвищення сигналу від іï стінок та їх потовщення. На МРТ рецидивна пухлина мала вигляд гіперінтенсивного утворення на Т2-33, з порушенням контурів $(72,7 \%)$ та структури піхви $(81,8 \%)$, локального потовщення стінки піхви $(85,4 \%)$, з інтенсивним накопиченням контрастної речовини на постконтрастних зображеннях $(87,0 \%)$. Пухлинна інвазія в паракольпос характеризувалася появою зон неправильної клиноподібної форми, що мали знижений сигнал порівняно з високим сигналом від жиру (рис. 6).

На підставі проведених досліджень визначено діагностичну інформативність УЗД і МРТ для виявлення метастатичного ураження піхви. Так, чутливість, специфічність і точність при 


\section{Оригінальні статті / Original Articles}

УЗД становили 75,0; 80,0 та 76,7\% відповідно, а при МРТ 85,$0 ; 90,0$ та $86,6 \%$ відповідно.

Дослідження упродовж консервативного лікування $\epsilon$ вкрай важливими, оскільки точна оцінка відповіді пухлини

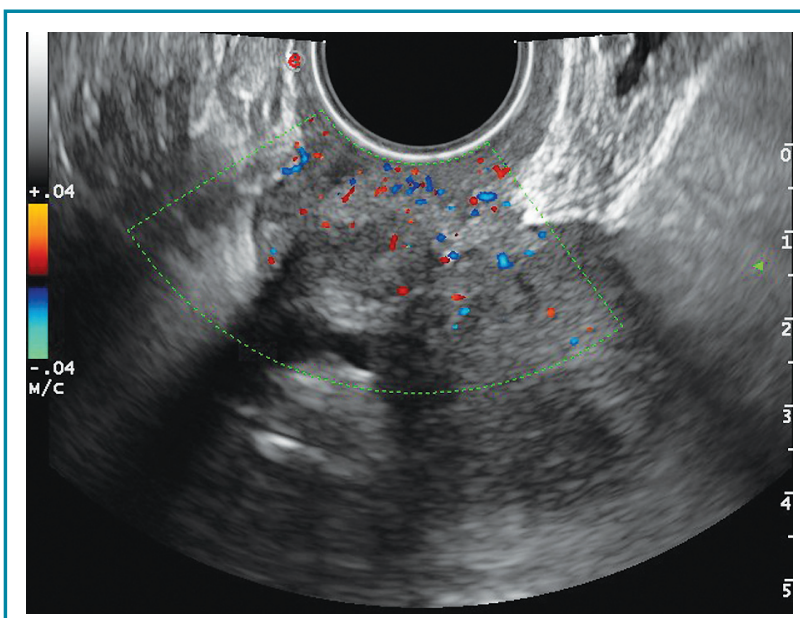

Рис. 4. Ехограма метастазу РШМ в піхві. РШМ ТЗа, стан після ХПТ, метастатична пухлина в склепіннях піхви. УТворення з горбистими нечіткими контурами, з атиповим кровотоком, поширюється на нижні відділи шийки матки на консервативну терапію - необхідна умова для своєчасної корекції лікування.

При ефективному лікуванні відмічалося поступове зменшення розмірів новоутворення. Згідно з критеріями RECIST (Response Evaluation Criteria in Solid Tumours) повний регрес реєстрували при зникненні пухлини, частковий - при зменшенні пухлини не менш ніж на 30\%, прогресію - при збільшенні пухлини не менш ніж на 20\%, стабілізацію процесу - коли динаміка захворювання не відповідала вищеозначеним критеріям.

При нашому дослідженні позитивну динаміку лікування відмічали у 16 випадках, з них у 6 пацієнток - повний, а у 10 жінок - частковий регрес захворювання. При повному регресі пухлина не визначалася, при частковому регресі зберігалася залишкова пухлинна інфільтрація, яка поступово заміщувалася фіброзом впродовж 1-2 міс після закінчення лікування (відстрочена реалізація ефекту променевої терапіі). Натомість у 4 пацієнток відповіді пухлини на проведене лікування не отримано - реєстрували стабілізацію неопроцесу.

Ми зіставили дані променевих методів у різні терміни: до, упродовж та після проведення консервативного лікування у хворих на метастатичні пухлини піхви. Аналізуючи УЗта МР-картини, ми виявили, що при ефективному лікуванні, крім зменшення об'єму новоутворення, нормалізуються структура та контури піхви. За наявності позитивної динаміки впродовж лікування у пацієнток при УЗД спостерігали зміни параметрів кровотоку: зменшення кількості судинних локусів, зниження $\mathrm{V}_{\max }$, підвищення RI. При регресі пухлини
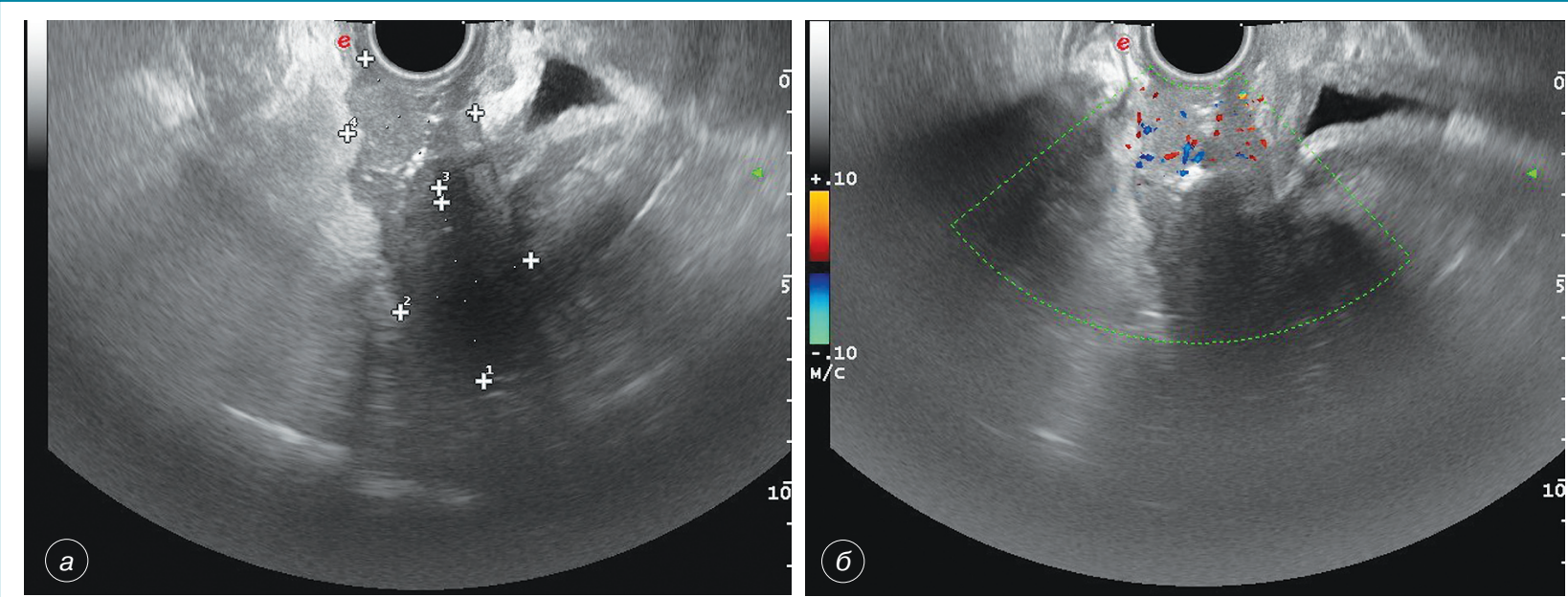

Рис. 5. Ехограми метастатичного ураження піхви. РШМ ТЗа, стан після ХПТ, тотальне ураження піхви з нерівномірно потовщеними, пухлинно-зміненими стінками, атиповим кровотоком: $а$ - в В-режимі; б - КДК
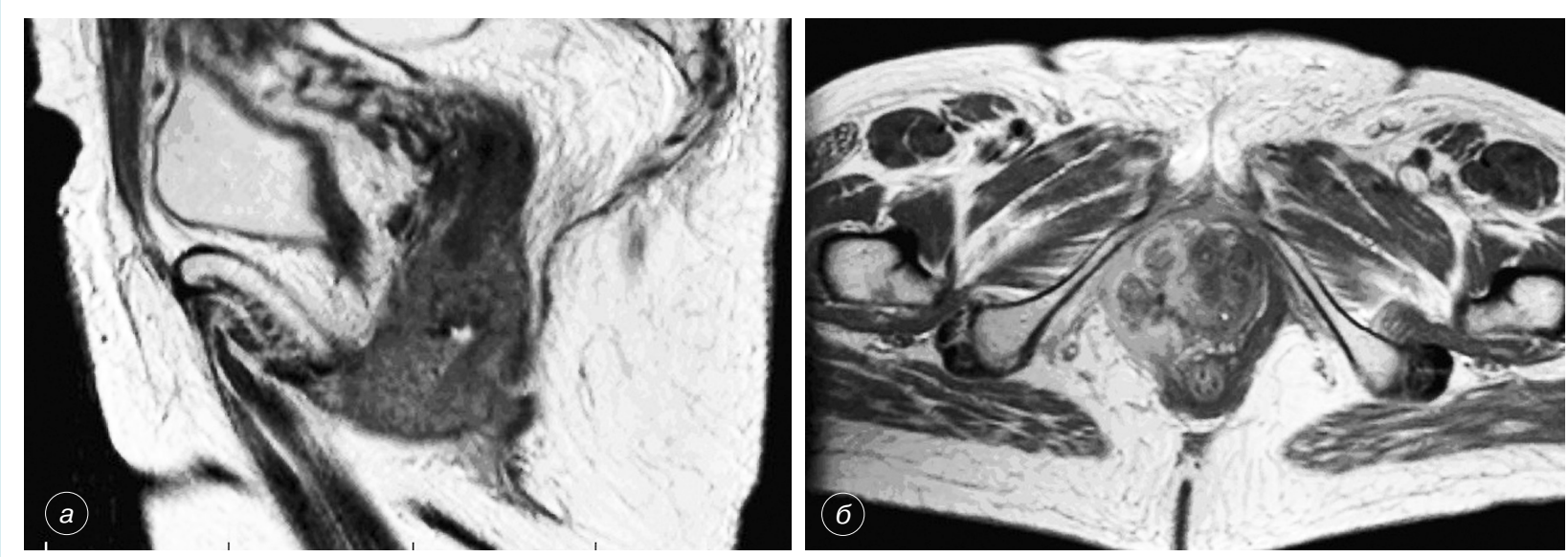

Рис. 6. МР-скани метастазу РШМ в піхві. РШМ ТЗб, стан після ХПТ, метастатична пухлина біля входу в піхву у вигляді гіперінтенсивного утворення на Т2-33 з порушенням контурів піхви (а), з інтенсивним накопиченням контрастної речовини на постконтрастних зображеннях (б) 

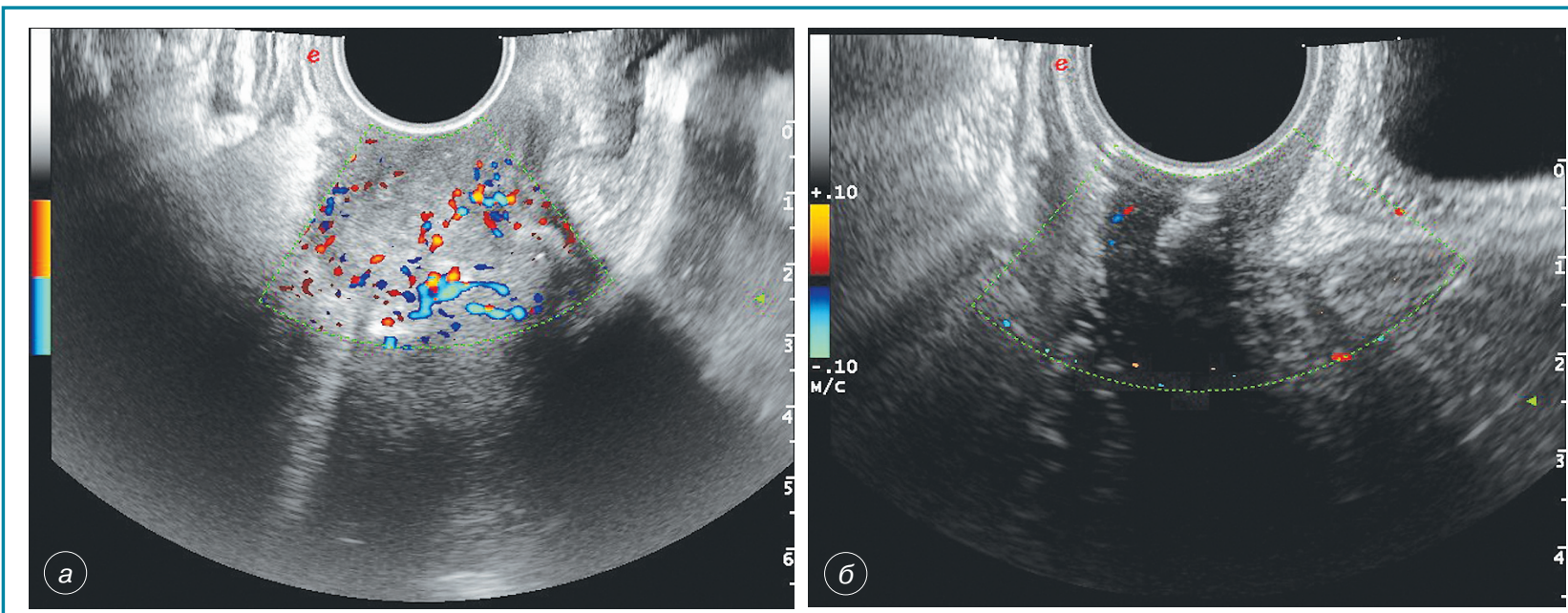

Рис. 7. Ехограми моніторингу ХПТ метастатичної пухлини піхви. РШМ Т2а, метастаз в піхві: а) до лікування в піхві візуалізується утворення з горбистими нечіткими контурами, з атиповим кровотоком; б) після закінчення лікування піхва з рівними непотовщеними стінками, пухлина не визначається, васкуляризація піхви не змінена
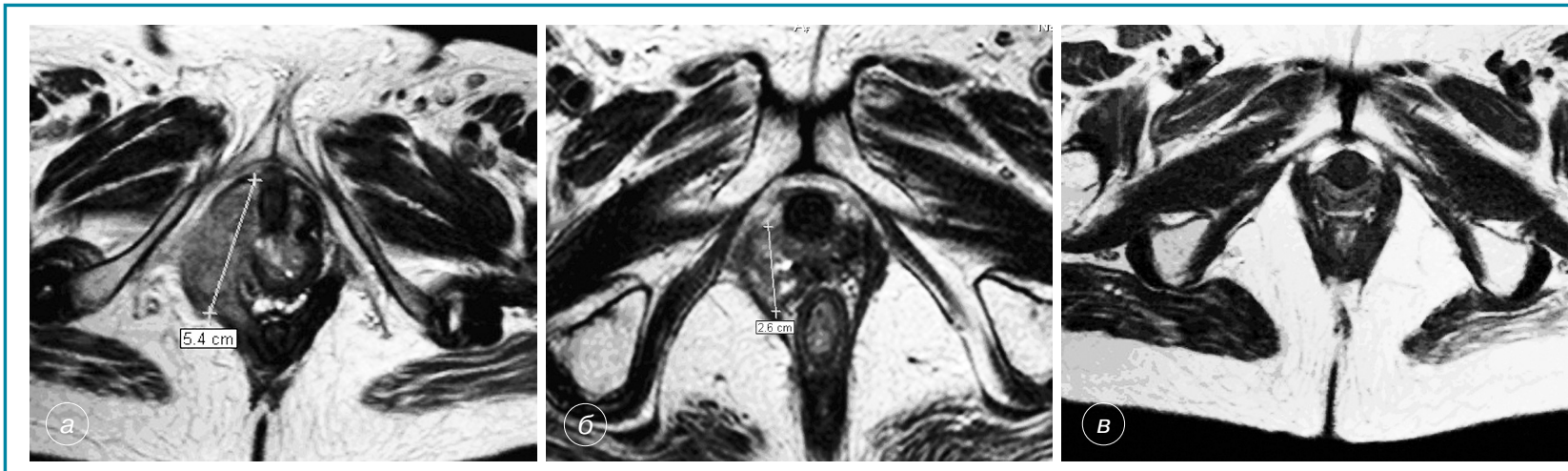

Рис. 8. МР-моніторинг ХПТ метастатичної пухлини піхви. РШМ Т2б, метастаз у піхві: а) до лікування в піхві візуалізується гіперінтенсивне утворення розмірами 54 мм в діаметрі з горбистими нечіткими контурами; б) після 1-го етапу ХПТ зменшення розмірів пухлини до 26 мм в діаметрі; в) після закінчення лікування піхва з рівними непотовщеними стінками, пухлина не визначається

реєстрували поодинокі судини з низькою систолічною $\mathrm{V}_{\max }$ $6,0 \pm 1,1 \mathrm{~cm} / \mathrm{c} \mathrm{та} \mathrm{RI} \mathrm{0,69 \pm 0,1} \mathrm{(рис.} \mathrm{7).}$

При регресі пухлини на МРТ фіксували зниження інтенсивності МР-сигналу від пухлинної тканини на Т2-33, відновлення нормальної зональної анатомії піхви та шийки матки, зниження інтенсивності накопичення контрастної речовини на постконтрастних Т1-33 (рис. 8).

Таким чином, УЗ-ознаками регресу рецидивного новоутворення внаслідок консервативного лікування, окрім зменшення об'єму пухлини, були більш чіткі, рівні контури (75,0\%), більш однорідна структура піхви (62,5\%), нормалізація кровотоку $(68,7 \%)$; МР-ознаками регресу пухлини також були зменшення пухлинної інвазії в паракольпос $(75,0 \%)$, зниження інтенсивності МР-сигналу від пухлинної тканини на Т2-33 $(87,5 \%)$, зниження інтенсивності накопичення контрастної речовини на постконтрастних Т1-33 (81,3\%).

На підставі проведених досліджень була визначена діагностична інформативність УЗД і МРТ в оцінці відповіді пухлини на проведену консервативну терапію у хворих із метастатичним ураженням піхви. Так, чутливість, специфічність і точність при УЗД становили 62,5; 75,0 та 65,0\% відповідно, а при МРТ - 75,0; 87,0 та 77,5\% відповідно.

\section{ВИСНОВКИ}

1. Чутливість, специфічність і точність для оцінки ефективності консервативної терапії метастатичного раку піхви при УЗД становила 75,0; 80,0 та 76,7\% відповідно, а при МРТ 85,$0 ; 90,0$ та $86,6 \%$ відповідно.

2. Чутливість, специфічність і точність для оцінки ефективності консервативної терапії метастатичного раку піхви при УЗД становили 62,5; 75,0 та 65,0\% відповідно, а при МРТ 75,0; 87,0 та 77,5\% відповідно.

3. УЗД та МРТ є інформативними методами для виявлення та оцінки ефективності консервативної терапії метастатичного раку піхви.

\section{СПИСОК РЕКОМЕНДОВАНОЇ ЛІТЕРАТУРИ}

1. Буланов М.Н. (2012) Ультразвуковая гинекология: курс лекций. Изд. 2-е, в 2 ч. ВИДАР, Москва, 560 с.

2. Васильев А.Ю., Ольхова Е.Б. (2008) Лучевая диагностика: учебник для студ. мед. вузов. ГЭОТАР-Медиа, Москва, 679 с.

3. Каргополова М.В., Максимов С.Я., Берлев И.В. идр. (2013) Возможности ипределы современныхметодов диагностики отдаленныхметастазов местно-распространенных форм рака шейки матки. Журн. акушерстваи женских болезней, 62(2): 172-178.

4. Гажонова В.Е., Мамаев В.В., Андрияничева Е.Н. (2006) Сравнительная оценка диагностической ценности УЗИ и МРТ в визуализации инвазивных форм рака шейки матки. Мед. визуализация, 2: 56-64.

5. Іванкова В.С., Нестеренко Т.М., Хруленко Т.В. та ін. (2015) Запобігання надмірної токсичності консервативної терапії хворих на місцево-поширені форми раку шийки матки. Укр. радіол. журн., 23(2): 87-91.

6. Конанихін В.І., Колпаков О.Є., Рижкова Ю.В. (2015) Ускладнення після комбінованого лікування у хворих на рак шийки матки. Укр. радіол. журн., 23(2): 135-137.

7. Крижанівська А.Є. (2013) Рецидиви у хворих на рак шийки матки IIB стадії. Галицький лікарський вісник, 20(3): 32-34.

8. Терновой С.К. и др. (2008) Лучевая диагностика и терапия: учебник для студ. мед. вузов: в 2 т. Медицина, Москва, 352 с.

9. Шавладзе 3.Н., Березовская Т.П., Прошин А.А., Крикунова Л.И. (2010) Магнитно-резонансная томография в прогнозировании эффективности лучевого и химио-лучевого лечения рака шейки матки. Мед. радиология и радиацион. безопасность, 55(4): 49-54. 
10. Іванкова В.С., Нестеренко Т.М., Храновська Н.М. та ін. (2014) Методи оцінки ефективності хіміопроменевого лікування хворих на поширений рак шийки матки. Укр. радіол. журн., 22(2): 22-26.

11. Федоренко З.П., Михайлович Ю.Й., Гулак Л.О. та ін. (2018) Рак в Україні, 2016-2017. Захворюваність, смертність, показники діяльності онкологічної служби. Бюл. Нац. канцер-реєстру України, 19: 121.

12. Крейнина Ю.М., Титова В.А., Добровольская Н.Ю., Болтенко А.И. (2007) Современные подходы к терапии рецидивов и метастазов рака шейки матки. Мед. радиология и радиацион. безопасность, 52(5): 36-45.

13. Базаева И.Я., Горбунова В.А., Кравец О.А. и др. (2014) Химиолучевая терапия местно-распространенного рака шейки матки. Вопросы онкологии, 60(3): $280-287$.

14. Лысак В.И., Гордеева Е.В., Мирошниченко И.В. и др. (2015) Химиолучевая терапия местно-распространенного ракашейки матки. Укр. радіол. журн., 23(2): 78-81

15. Vincens E., Balleyguier C., Rey A. et al. (2008) Accuracy of magnetic resonance imaging in predicting residual disease in patients treated for stage IB2/II cervical carcinoma with chemoradiation therapy: correlation of radiologic findings with surgicopathologic results. Cancer, 113(8): 2158-2165

16. Gottwald L., Lech W., Sobotkowski J. et al. (2009) Clinical research transvaginal doppler sonography for assessment the response to radiotherapy in locally advanced squamous cervical cancer: a preliminary study. Arch. Med. Sci., 5(3): 459-464.

17. Kim H., Woochul K., Mijo L. (2007) Tumor volume and uterine body invasion assessed by MRI for prediction of outcome in cervical carcinoma treated with concurrent chemotherapy and radiotherapy. Jpn J. Clin. Oncol., 37(11): 858-866.

18. Narayan K., Fisher R., Bernshaw D. (2006) Significance of tumor volume and corpus uteri invasion in cervical cancer patients treated by radiotherapy. Int. J. Gynecol Cancer, 16(2): 623-630.

19. Pecorelli S. (2009) Revised FIGO staging for carcinoma of the vulva, cervix, and endometrium. Int. J. Gynaecol. Obstet., 105(2): 103-104.

\section{Лучевые методы исследования в мониторинге лечения больных метастатическим раком влагалища}

Т.С. Головко, В.С. Иванкова, О.А. Бакай, Л.А. Шевчук, Л.М. Барановская

\section{Национальный институт рака, Киев}

Резюме. Главная задача динамического наблюдения пациенток в отдаленные сроки после проведения консервативного лечения - своевременное выявление рецидива заболевания. Для этого применяют лучевые методы, прежде всего ультразвуковое исследование (УЗИ) и магнитно-резонансную томографию (МРТ). Цель работы - определить информативность лучевых методов исследования в мониторинге лечения больных с метастатическим раком влагалища. Объект и методы исследования. Проведено комплексное лучевое обследование с применением УЗИ и МРТ у 20 больных с метастатическим раком влагалища до, во время и после сочетанного лучевого лечения на фоне использования химиорадиомодификаторов для оценки его эффективности. Контрольная группа - 10 пациенток без признаков продолжения болезни. УЗ- и МР-семиотика сопоставлена с клиническим течением болезни и данными морфологического исследования. Результаты. Определены УЗ- и МР-признаки метастатического рака влагалища и его регресса вследствие консервативного лечения. Чувствительность, специфичность и точность в выявлении метастатического рака влагалища при УЗИ составляли 75,0; 80,0 и 76,7\%, при МРТ 85,$0 ; 90,0$ и 86,6\% соответственно. Чувствительность, специ- фичность и точность оценки эффективности консервативной терапии метастатического рака влагалища при УЗИ составили 62,$5 ; 75,0$ и $65,0 \%$, при МРТ - 75, $0 ; 87,0$ и 77, $5 \%$ соответственно. Выводы. УЗИ и МРТ являются информативными методами для выявления и оценки эффективности консервативной терапии метастатического рака влагалища.

Ключевые слова: ультразвуковая диагностика; магнитнорезонансная томография; метастатический рак влагалища; химиолучевая терапия.

Radial research methods in monitoring the treatment of patients with metastatic vaginal cancer

T.S. Golovko, V.S. Ivankova, O.O. Bakai, L.A. Shevchuk, L.M. Baranovska National Cancer Institute, Kyiv

Summary. The main task of the dynamic observation of patients in the long-term periods after the conservative treatment is the timely detection of the disease recurrence. For this purpose, radiation methods, first of all, ultrasound and magnetic resonance imaging (MRI) are used. Objective - estimate the radiation research methods in monitoring the treatment of patients with metastatic vaginal cancer. Materials and methods. A complex radiological examination was performed using ultrasound and MRI of 20 patients with metastatic vaginal cancer before, during and after combined radiation treatment while using chemoradiomodifiers to assess its effectiveness. The control group -10 patients with no signs of continuing illness. Ultrasound and MR-semiotics are compared with the clinical course of the disease and morphological study data. Results. Ultrasound and MRI signs of metastatic vaginal cancer and regression of recurrent neoplasm due to conservative treatment were determined. The sensitivity, specificity and accuracy in detecting of metastatic vaginal cancer with ultrasound were $75.0 ; 80.0$ and $76.7 \%$, with MRI - 85.0; 90.0 and $86.6 \%$ respectively. The sensitivity, specificity and accuracy of evaluating the effectiveness of conservative treatment of metastatic vaginal cancer with ultrasound were $62.5 ; 75.0$ та $65.0 \%$, with MRI - 75.0; 87.0 and $77.5 \%$ respectively. Conclusions. Ultrasound and MRI are informative methods for detecting and evaluating the effectiveness of conservative treatment of metastatic vaginal cancer.

Key words: ultrasound diagnostics; magnetic resonance imaging; metastatic vaginal cancer; chemo-radiation therapy.

Адреса:

Бакай Ольга Олексіївна

О3О22 Київ, вул. Ломоносова, 33/43

Національний інститут раку

E-mail: bakaiolga1050@gmail.com 